\title{
Antik Konuralp Kentinde Tarihsel Dönem Depremlerinin Antik Yapılara Etkisinin ve İzlerinin Araştırılması
}

\author{
Ali Ateş ${ }^{1 *}$ \\ 1*Bolu Abant İzzet Baysal Üniversitesi, Mühendislik Fakültesi, İnşaat Mühendisliği Bölümü, Bolu, Türkye, (ORCID:0000-0001-6297-85-71), aliates@ ibu.edu.tr
} (İlk Geliş Tarihi 18 Mayıs 2021 ve Kabul Tarihi 4 Ağustos 2021)

(DOI: 10.31590/ejosat.938673)

ATIF/REFERENCE: Ateş, A. (2021). Antik Konuralp Kentinde Tarihsel Dönem Depremlerinin Antik Yapılara Etkisinin ve İzlerinin Araştırılması. Avrupa Bilim ve Teknoloji Dergisi, (25), 582-593.

$\ddot{O} \mathbf{z}$

Düzce ili Dünyada ve Türkiye'de aktif hareketliliğin en yoğun olarak yaşandığı bir kuşak üzerindedir. Avrupa ve Asya kıtaları arasında, Karadeniz ve Akdeniz ile sınırlanan sismik bir bölgede yer almaktadır. Çalışma alanını etkileyen en önemli fay ise Kuzey Anadolu Fay Zonu'dur (KAFZ). KAFZ sismik aktivite yüksek olan bir fay zonudur. 17 Ağustos 1999 İzmit ve 12 Kasım Düzce Depremi bu fay zonu üzerinde meydana gelmiştir. Ayrıca bu bölgede yıkıcı hasarlar, can ve mal kayıpları meydana gelmiştir. Tarihi ve aletsel kayıtlara bakıldığında yıkıcı depremlerin meydana geldiği tarihi kalıntılardan ve yeraltında kalmış enkazlardan anlaşılmaktadır. Bu çalışmada Düzce ilinde yer alan ve tarihi ve arkeolojik harabeler ve tarihi Prusias kentinin de yok olmasına sebep olmuş tarihsel dönem depremleri ve izleri araştırılmıştır. Ayrıca, Konuralp yerleşkesi çevresinde bulunan antik kentteki bazı tarihi yapılarda tarihsel depremlerin meydana getirdiği izler ve arkeolojik kalıntılardan örnekler sunulmuştur. Bu araştırmada tarihi antik kentlerdeki Roma dönemine ait bazı tarihi kalıntıların karakteristikleri belirtilerek oluşan depremler neticesinde meydana gelen hasarlar incelenmiştir. Araştırma sonunda Konuralp çevresinde meydana gelen yer hareketlerinin etkilediği antik dönem yapılarının bu depremler sonucunda tamamen yıkıldığı sonucuna varılmıştır.

Anahtar Kelimeler: Konuralp (Düzce), tarihsel dönem depremler, antik harabeler, Roma kalıntıları

\section{Investigations of the Effect and Traces of Historical Period of Earthquake to the Antique Structures in the Antique Konuralp City}

\begin{abstract}
Düzce province is located where the land has the most movability; this is seen on the belt in the World. It is located in a seismic zone between the European and Asian continents bordered by the Black Sea and the Mediterranean. The most important fault affecting the study area is the North Anatolian Fault Zone (NAFZ). NAFZ is a fault zone which has high activity. The earthquake of the 17 th of August 1999, located in İzmit and the earthquake of the 12 th of November in Düzce, has occurred on this fault zone, with devastating damages, loss of life and property under the light of looking at the historical and instrumental records, it is understood from the historical remains and underground debris that devastating earthquakes have occurred. The earthquakes have been investigated and traced to the ancient city of Prusias in Düzce Province, where the destruction of historic magnitude and archaeological ruins have been discovered. In addition, the samples which belong to the historical ruins created by the earthquakes could have now been seen on the ancient structures in the historic city around the Konuralp campus. In this research, the characteristics of some historical ruins belonging to the Roman period in historical ancient city was determined and damages caused by earthquakes were investigated. At the end of the research, it is was concluded that the ancient period of buildings affected by the ground movements which occurred in Konuralp Campus were completely destroyed as the result of these earthquakes.
\end{abstract}

Keywords: Konuralp (Düzce), historical earthquakes, historical ruins, Roman ruins

*Sorumlu Yazar: aliates@ibu.edu.tr 


\section{Giriş}

Türkiye, Doğu Anadolu sınırımızda İran'dan başlayarak, yine ülkemizin batı sınırında Tekirdağ körfezimde sonlanan Kuzey Anadolu Fayı (KAF) ve ayrıca Arap Plakasının devamı niteliğinde olan Bitlis-Zagros Bindirme bölgesi olarak tanımlanan fay zonuna paralel bir şekilde Türkiye'nin doğusundan başlayarak Türkiye'nin güneyinde son bulan Doğu Anadolu Fay Zonu ile sınırlandırılmıştır. Türkiye, Alpin sisteminin kuzey ve güneyden etkisi altında olduğu için Hersiniyen Orojenize ait izler, genel olarak bozulmuştur. Kuzeydeki kol, tektonik bakımdan tali bölümlere ayrılmaktadır [1]. Kuzey Anadolu'da doğu batı doğrultusunda uzanan devamlı bir çöküntü alanı yer alır. Saros körfezinden başlayarak Kuzey Marmara çukurunu ve Düzce - Bolu depresyon alanını içine alan bir hat mevcuttur. Bu hat Kelkit vadisi, Erzincan Erzurum Pasinler'i içine alarak Aras çukurluğu ile Türkiye'den çıkmaktadır [1].

$\mathrm{Bu}$ bağlamda Ülkemiz aktif bir deprem kuşağı üzerinde bulunmaktadır. Bu fay zonlarına ilave olarak Ege bölgesi Batı Anadolu fay zonu da aktivitesi ile aktif deprem bölgeleri arasındadır. $\mathrm{Bu}$ bağlamda aletsel dönem ve tarihsel kayıtlara bakıldığında çok sayıda yıkıcı depremler yaşanmıştır. Bu yıkıcı depremlerin son örneği 30 Ekim 2020'de İzmir'de $(\mathrm{Mw}=6,9) 6,9$ büyüklügüunde bir deprem meydana gelmiş, can ve mal kayıplarına neden olmuştur. Düzce, aktif bir deprem kuşağı içinde yer almaktadır. Tektonik bakımdan çok hareketli olan bu bölge Düzce'de de etkisini göstermektedir. Düzce ve çevresinin zemin yapısı henüz oturmuş ve yerleşmiş jeolojik bir yapıda değildir. Düzce bölgesi tarihsel ve aletsel dönemlerde de çok sayıda deprem yaşamıştır. Son dönemde 17 Ağustos 1999'da Adapazarı İzmit depremi 7,4 büyüklüğünde bir deprem olarak kayıtlara geçmiştir.

Bu depremin devamında 12 Kasım 1999 tarihinde Düzce'de 7,2 büyüklüğünde bir deprem meydana gelmiştir. Bu depremlerde bölgede çok sayıda can ve mal kayıpları yaşanmıştır. Bu bölge aktivitesinin yüksekliği ile bilinmektedir $[1,2]$. Bu çalışmada Düzce ve Çevresinin tarihsel dönem depremlerinin bu bölgede yaşamış uygarlıklara ve uygarlıkların meydana getirdiği antik yapıları etkisi araştırılmıştır. Bu bağlamda bu bölgede olmuş depremler ve yine bu bölgenin depremselliği ve etkileri araştırılmıştır.

\section{Konuralp ve Çevresinin Depremselliği}

Düzce ve çevresi depremsellik açısından ülkemizin ve Dünyanın aktif ve risk seviyesi yüksek, bir deprem kuşağ 1 üzerindedir. Ve çalışma bölgesi Kuzey Anadolu Fay Zonu'nun (KAFZ) etki alanı içindedir. Anadolu levhası, Avrasya ve Arap levhasının etkisi ile Batı yönünde Helenik Yay tarafına doğru saatin tersi yönünde hareket etmektedir. Afrika Levhası ise Helenik Yay ve Kıbrıs Yayı boyunca Anadolu levhasının altına doğru ilerlemektedir [3].

Asya-Avrupa levhası ile güneyde Anadolu levhacığını birbirinden ayıran Kuzey Anadolu Fay Zonu (KAFZ), yaklaşık uzunluğu $1200 \mathrm{~km}$ olan sağ yönlü doğrultu atımlı bir fay sistemi olup ülkemizin en önemli tektonik yapılarından biridir ve bu fay sisteminin çalışma alanını da etkileyeceği bilinmektedir. 17 Ağustos ve 12 Kasım 1999 depremlerinin bu zon üzerinde meydana gelmesi aktivitenin devam ettiğinin açık bir işaretidir. Türkiye Diri Fay Haritasında çalışma alanı ve çevresinde risk oluşturabilecek 3 adet diri fayın mevcut olduğu bilinmektedir [4]. Bunlar;

Düzce Fay1; Düzce Havzasını morfolojik olarak Düzce ilini güneyden sinırlandıran bu fay, Akyazı, Düzce arasında toplam $80 \mathrm{~km}$ uzunluğundadır. Birbirini bütünleyen üç alt parçadan (segment) oluşan Düzce Fayı sağ yönlü doğrultu atımlı sismik olarak aktivitesi belirgin faydır. Fayın Akyazı bölümünde Kuvaterner öncesi temel kayalar içerisinden geçtiği izlenmektedir. $\mathrm{Bu}$ fay sistemi aktivitesini 17 Ağustos ve 12 Kasım depremleriyle de ortaya koymuştur. 17 Ağustos depreminde $(\mathrm{M}=7,4)$ gelişmiş olan $130 \mathrm{~km}$. uzunluğundaki yüzey kırığının 30 km'lik doğu segmenti Düzce Fayı üzerinde bulunmaktadir.

Hendek Çilimli Fayı Düzce Havzası batısında Sapanca GölüHendek-Cumayeri arasında uzanan D-GB uzanımlı fay Hendek Fayı olarak adlandırılmaktadır. Sağ yönlü doğrultu atımlı olan bu fay yaklaşık $50 \mathrm{~km}$ uzunluğunda olduğu bilinmektedir [4]. Adapazarı Ovasında olası olarak haritalanmış olan bu fay Hendek-Cumayeri arasında 25 km'lik bölümünde morfolojik olarak çok belirgin bir şekilde mostra vermektedir. Morfolojide sağ yönde ötelenmeler ve büyük boyutlu basınç sırtlarının gelişmiş olduğu zonda Pliyo-Kuvaterner yaslı Karapürçek formasyonu bu fay tarafindan kesilmekte, fay bu formasyonla temel kayalar arasında dokanak oluşturmakta, doğu bölümünde ise temel kayalar içerisinde devam etmektedir. 1994 DüzceHendek depremi $(\mathrm{M}=6,5)$ olasılıkla bu fay üzerinde gerçekleşmiş olduğu bilinmektedir [4,5]. Fay üzerinde son depremlerde Hendek'in kuzeybatısında yüzey kırığı tespit edilmiş ve gözlenmiştir. Oluşan bu kırık sağ yönlü doğrultu atımlıdır. Kırık boyunca küçük boyutlu deformasyonlar, $2-5 \mathrm{~cm}$. arasında sağ yönlü ötelenmeler ve kaymalar gelişmiştir. Fay üzerinde tespit edilen ve boyutu ile oransız olan bu yüzey kırılması 17.08.1999 depremiyle Hendek fayı üzerinde aşırı stres birikiminin olduğunu gösteren bir veri olarak kabul edilmektedir [4,5]. Çalışma alanının etkisi altında olduğu diri faylar Şekil 1 'de sunulmuştur.

KAFZ ve etkisi altında olan çalışma alanında geçmişten günümüze kadar tarihsel ve aletsel kayıtlarda bir çok deprem kaydı mevcuttur. Bunlardan en önemlileri ve son depremler 17 A $\breve{g}_{1 s t o s} 1999(\mathrm{Mw}=7,4)$ ve 12 Kasım $1999 \quad(\mathrm{Mw}=7,2)$ depremleridir [5].

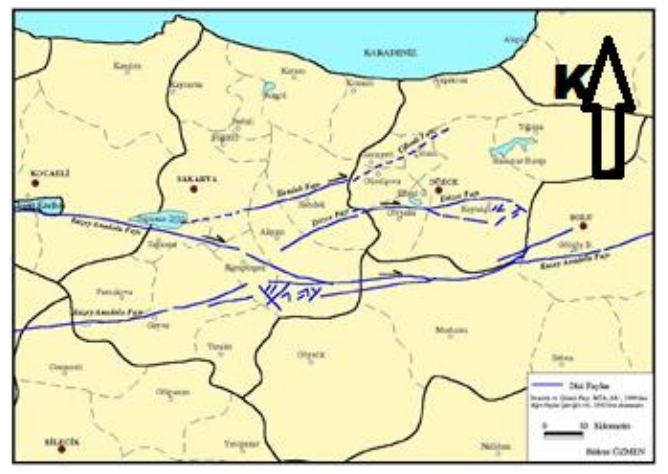

Şekil 1. Çalışma alanı tektonik yapı ve Düzce Fayının kolları (Özmen 2000'den alınmıştır) [5] 


\subsection{Konuralp ve Çevresinin Deprem Tehlike Analizi}

Düzce ve Çevresini etkileyen aletsel dönem depremleri (1900-2016) Kandilli Rasathanesi Deprem Araştırma Enstitüsünün deprem verilerinden derlenmiş ve deprem risk

analizlerinde bu veriler kullanılmıştır. 1900 ila 24.07.2016 y1lları arasında $100 \mathrm{~km}$ 'lik bir dairesel yarı çapta, magnitüdü 4,5-7,5 arasında olan 132 adet deprem kayıtlara geçmiştir (Çizelge 1), (Şekil 2, 3), [6].

Çizelge1. Çalışma alanında 100 km'lik çap içinde meydana gelen tarihsel depremler [6]

\begin{tabular}{|c|c|c|c|c|c|c|}
\hline No & Deprem Kodu & Enlem & Boylam & $\operatorname{Der}(\mathrm{Km})$ & M & Yer \\
\hline 1 & 20141022171105 & 40.4065 & 30.1147 & 007.5 & 4.5 & Taşoluk-Geyve (Sakarya) [South West 3.4 Km] \\
\hline 2 & 20131124204937 & 40.7848 & 31.8763 & 007.6 & 4.6 & Ulumescit (Bolu) [North East $0.4 \mathrm{Km}$ ] \\
\hline 3 & 20060208040741 & 40.7108 & 30.3648 & 008.7 & 4.5 & Arifiye (Sakarya) [South East $0.4 \mathrm{Km}$ ] \\
\hline 4 & 20040413214722 & 40.7500 & 31.6400 & 0010 & 4.6 & Yeniköy (Bolu) [South $2.6 \mathrm{Km}]$ \\
\hline 5 & 20030521082150 & 40.7800 & 30.9600 & 0014 & 4.5 & Yeşilova-Gölyaka (Duzce) [North East $0.6 \mathrm{Km}]$ \\
\hline 6 & 20010826004112 & 40.9800 & 31.5400 & 0006 & 4.6 & Ciftlik-Yığılca (Düzce) [South $0.9 \mathrm{Km}$ ] \\
\hline 7 & 20000823134127 & 40.7100 & 30.7500 & 0009 & 5.0 & Çamlıca-Hendek (Sakarya) [North West $0.6 \mathrm{Km}]$ \\
\hline 8 & 20000214065634 & 40.9800 & 31.7800 & 0009 & 4.8 & Yeșilöz-Devrek (Zonguldak) [South West 7.3 Km] \\
\hline 9 & 19991213191337 & 40.7000 & 30.7400 & 0007 & 4.7 & Camlıca-Hendek (Sakarya) [South West $1.3 \mathrm{Km}$ ] \\
\hline 10 & 19991119195907 & 40.7800 & 30.9700 & 0009 & 5.0 & Yazlik-Gölyaka (Düzce) [South West $0.4 \mathrm{~km}$ ] \\
\hline 11 & 19991117081526 & 40.8000 & 31.4600 & 0009 & 5.0 & Kızılağıl (Bolu) [North West $5.9 \mathrm{Km}$ ] \\
\hline 12 & 19991116175117 & 40.7900 & 31.6000 & 0001 & 4.9 & Kozlu (Bolu) [South West $1.3 \mathrm{Km}$ ] \\
\hline 13 & 19991113025200 & 40.7800 & 30.3000 & 0010 & 4.7 & Cubuklu-Serdivan (Sakarya) [North East $0.3 \mathrm{Km}$ ] \\
\hline 14 & 19991113005400 & 40.7200 & 31.0000 & 0010 & 4.7 & Bakacak-Gölyaka (Duzce) [South East $2.4 \mathrm{Km}$ ] \\
\hline 15 & 19991112222100 & 40.7500 & 31.3900 & 0010 & 4.8 & Darıyeri bakacak-Kaynaslı (Duzce) [East $0.4 \mathrm{Km}$ ] \\
\hline 16 & 19991112205400 & 40.7600 & 31.3800 & 0010 & 4.5 & Dariyeri bakacak-Kaynaslı (Duzce) [North West $1.2 \mathrm{Km}]$ \\
\hline 17 & 19991112200500 & 40.7400 & 31.0000 & 0010 & 4.5 & Yunusefendi-Gölyaka (Duzce) [South West $1.1 \mathrm{Km}$ ] \\
\hline 18 & 19991112191600 & 40.7400 & 31.3800 & 0010 & 4.7 & Yeşiltepe-Kaynash (Duzce) [North East $0.2 \mathrm{Km}$ ] \\
\hline 19 & 19991112190700 & 40.7700 & 31.2000 & 0010 & 4.5 & Güven (Düzce) [South West $0.5 \mathrm{Km}$ ] \\
\hline 20 & 19991112182400 & 40.7600 & 31.1100 & 0010 & 4.7 & Aydınpınar (Düzce) [South East $0.3 \mathrm{Km}$ ] \\
\hline 21 & 19991112181400 & 40.7500 & 31.3600 & 0010 & 5.0 & Yeşiltepe-Kaynash (Duzce) [North West $2.0 \mathrm{Km}$ ] \\
\hline 22 & 19991112180500 & 40.7000 & 31.7000 & 0010 & 4.7 & Demirciler (Bolu) [North East $1.8 \mathrm{Km}]$ \\
\hline 23 & 19991112175700 & 40.7400 & 31.4000 & 010 & 4.8 & Darıyeri bakacak-Kaynaslı (Duzce) [South East $1.6 \mathrm{Km}$ ] \\
\hline 24 & 19991112175400 & 40.7700 & 31.2600 & 0010 & 4.7 & Findıkl1-Kaynaşlı (Duzce) [South East $0.4 \mathrm{Km}$ ] \\
\hline 25 & 19991112175200 & 40.7600 & 31.2200 & 0010 & 4.8 & Özyanık (Düzce) [South West 1.4 Km] \\
\hline 26 & 19991112174700 & 40.7200 & 30.9500 & 0010 & 4.8 & Saçmalıpınar-Gölyaka (Duzce) [South $1.7 \mathrm{Km}$ ] \\
\hline 27 & 19991112173000 & 40.7500 & 31.4500 & 0010 & 5.2 & Elmalık (Bolu) [North $2.2 \mathrm{Km}]$ \\
\hline 28 & 19991112172700 & 40.7500 & 31.4000 & 0010 & 5.2 & Dariyeri bakacak-Kaynaslı (Duzce) [East $1.2 \mathrm{Km}$ ] \\
\hline 29 & 19991112172300 & 40.7600 & 31.1600 & 0010 & 5.1 & Kaledibi- (Düzce) [South West $1.3 \mathrm{Km}$ ] \\
\hline 30 & 19991112171800 & 40.7400 & 31.0500 & 0010 & 5.4 & Hamamüstü-Gölyaka (Duzce) [South East $1.2 \mathrm{Km}$ ] \\
\hline 31 & 19991112171700 & 40.7500 & 31.1000 & 0010 & 5.2 & Aydınpınar (Düzce) [South West 1.6 Km] \\
\hline 32 & 19991112165720 & 40.7400 & 31.2100 & 0025 & 7.2 & Uğur (Düzce) [North East $0.3 \mathrm{Km}$ ] \\
\hline 33 & 19991111144125 & 40.7400 & 30.2700 & 0022 & 5.7 & Așağıdereköy-Serdivan (Sakarya) [South $1.6 \mathrm{Km}$ ] \\
\hline 34 & 19991107165442 & 40.7100 & 30.7000 & 0010 & 5.0 & Altındere-Akyazı (Sakarya) [North $2.1 \mathrm{Km}$ ] \\
\hline 35 & 19990917194906 & 40.7200 & 30.1000 & 0015 & 4.5 & Sirinsulhiye-Kartepe (Kocael1) [North $2.3 \mathrm{Km}$ ] \\
\hline 36 & 19990913115528 & 40.7700 & 30.1000 & 0019 & 5.8 & Bayraktar-Izmit (Kocael1) [South East $2.0 \mathrm{Km}$ ] \\
\hline 37 & 19990831083323 & 40.7800 & 29.9600 & 0010 & 4.6 & Izmit (Kocaeli) [North East $3.1 \mathrm{Km}$ ] \\
\hline 38 & 19990831081051 & 40.7500 & 29.9200 & 0017 & 5.2 & Kocaeli [South West 0.8 \\
\hline 39 & 19990829101455 & 40.8800 & 31.2300 & 0007 & 4.8 & Esentepe (Düzce) [South West $1.6 \mathrm{Km}$ ] \\
\hline 40 & 19990822143059 & 40.7400 & 30.6800 & 0005 & 5.0 & Ortaköy-Hendek (Sakarya) [North East $0.9 \mathrm{Km}$ ] \\
\hline 41 & 19990819130412 & 40.7900 & 30.5800 & 0006 & 4.8 & Catalköprü-Akyazı (Sakarya) [North East $1.1 \mathrm{Km}$ ] \\
\hline 42 & 19990817211407 & 40.4900 & 31.0200 & 0006 & 4.5 & Güveytepe-Mudurnu (Bolu) [South East $1.1 \mathrm{Km}$ ] \\
\hline
\end{tabular}


European Journal of Science and Technology

\begin{tabular}{|c|c|c|c|c|c|c|}
\hline 43 & 19990817115809 & 40.5700 & 30.5100 & 0016 & 4.5 & Belpınar-Geyve (Sakarya) [North East $3.8 \mathrm{Km}$ ] \\
\hline 44 & 19990817090212 & 40.7700 & 31.1100 & 0016 & 5.0 & Çnarlı (Düzce) [North West $0.2 \mathrm{Km}]$ \\
\hline 45 & 19990817031401 & 40.6400 & 30.6500 & 0015 & 5.5 & Kuzuluk-Akyazı (Sakarya) [North East $1.5 \mathrm{Km}]$ \\
\hline 46 & 19990817000137 & 40.7600 & 29.9700 & 0018 & 7.4 & Başiskele (Kocaeli) [North East $2.0 \mathrm{Km}$ ] \\
\hline 47 & 19790628212209 & 40.7800 & 31.8500 & 0000 & 4.7 & Yayladınlar- (Bolu) [South East $0.8 \mathrm{Km}$ ] \\
\hline 48 & 19700419133341 & 40.0000 & 30.9000 & 010.0 & 5.3 & Taycılar-Tepebasș (Eskısehır) [North West $2.4 \mathrm{Km}$ ] \\
\hline 49 & 19690212084305 & 40.7000 & 30.2900 & 030.0 & 4.6 & Uzunkum-Sapanca (Sakarya) [West $1.8 \mathrm{Km}$ ] \\
\hline 50 & 19680328171220 & 40.5000 & 31.3400 & 006.0 & 4.8 & Dedeler-Mudurnu (Bolu) [South East $2.4 \mathrm{Km}$ ] \\
\hline 51 & 19680318054000 & 40.8300 & 30.5300 & 039.0 & 4.7 & Yeșilyurt-Adapazarı (Sakarya) [North East $1.4 \mathrm{Km}$ ] \\
\hline 52 & 19670918233934 & 40.8600 & 30.3000 & 033.0 & 4.5 & Nasuhlar-Adapazarı (Sakarya) [South $2.3 \mathrm{Km}$ ] \\
\hline 53 & 19670814200925 & 40.7400 & 30.3700 & 025.0 & 4.8 & Serdivan (Sakarya) [South East $2.8 \mathrm{Km}$ ] \\
\hline 54 & 19670814113419 & 40.6800 & 30.2700 & 033.0 & 4.5 & Nailiye-Sapanca (Sakarya) [North West $0.2 \mathrm{Km}$ ] \\
\hline 55 & 19670814014556 & 40.7500 & 30.3800 & 023.0 & 4.5 & Serdivan (Sakarya) [South East2.3 Km] \\
\hline 56 & 19670802153323 & 40.6700 & 30.4600 & 030.0 & 4.5 & Kayalar Resitbey-Erenler (Sakarya) [South East 1.9 Km] \\
\hline 57 & 19670801010510 & 40.4000 & 30.4000 & 046.0 & 4.5 & Aydınlar-Geyve (Sakarya) [South East $1.6 \mathrm{Km}$ ] \\
\hline 58 & 19670801001334 & 40.7200 & 30.5200 & 026.0 & 4.9 & Teketaban-Karapürçek (Sakarya) [North $3.8 \mathrm{Km}$ ] \\
\hline 59 & 19670730190548 & 40.7000 & 30.8000 & 010.0 & 4.5 & Bakacak-Hendek (Sakarya) [South West $0.5 \mathrm{Km}$ ] \\
\hline 60 & 19670730185846 & 40.7500 & 30.4600 & 027.0 & 4.8 & Kücük Esence-Erenler (Sakarya) [South West 3.7 Km] \\
\hline 61 & 19670730102510 & 40.7700 & 30.5600 & 022.0 & 4.5 & Çatal Köprü-Akyazı (Sakarya) [South West $1.9 \mathrm{Km}$ ] \\
\hline 62 & 19670730015718 & 40.7000 & 30.5800 & 007.0 & 4.5 & Meșepinar1-Karapürçek (Sakarya) [North East $3.1 \mathrm{Km}$ ] \\
\hline 63 & 19670730013101 & 40.7200 & 30.5200 & 018.0 & 5.7 & Teketaban-Karapürçek (Sakarya) [North $3.8 \mathrm{Km}$ ] \\
\hline 64 & 19670730011931 & 40.7100 & 30.5800 & 023.0 & 4.9 & Bediltahirbey-Akyazı (Sakarya) [South East $4.0 \mathrm{Km}$ ] \\
\hline 65 & 19670726091606 & 40.6100 & 30.6700 & 021.0 & 4.6 & Șerefiye-Akyazı (Sakarya) \\
\hline 66 & 19670723231914 & 40.6100 & 30.6300 & 015.0 & 4.6 & Taşburun-Akyazı (Sakarya) [East $1.1 \mathrm{Km}$ ] \\
\hline 67 & 19670723155709 & 40.6300 & 30.5900 & 023.0 & 4.7 & Bickidere-Akyazı (Sakarya) [North East $1.2 \mathrm{Km}]$ \\
\hline 68 & 19670723074223 & 40.7400 & 30.3600 & 011.0 & 4.4 & Serdivan (Sakarya) [South $2.6 \mathrm{Km}$ ] \\
\hline 69 & 19670723044855 & 40.6300 & 30.3600 & 033.0 & 4.9 & Boğazkoy-Geyve (Sakarya) [South $1.7 \mathrm{Km}$ ] \\
\hline 70 & 19670723040339 & 40.6100 & 30.3500 & 021.0 & 4.8 & Findıksuyu-Geyve (Sakarya) [North West $1.3 \mathrm{Km}$ ] \\
\hline 71 & 19670722234159 & 40.6400 & 30.5300 & 030.0 & 4.9 & Karapürçek (Sakarya) [South West $0.9 \mathrm{Km}$ ] \\
\hline 72 & 19670722220835 & 40.8000 & 30.5200 & 040.0 & 4.6 & Hacılar-Adapazarı (Sakarya) [South East $1.2 \mathrm{Km}$ ] \\
\hline 73 & 19670722212741 & 41.0000 & 30.4500 & 049.0 & 4.8 & Konuklu-Ferizli (Sakarya) [North West $0.6 \mathrm{Km}$ ] \\
\hline 74 & 19670722212141 & 41.0000 & 30.4500 & 0.490 & 4.9 & Konuklu-Ferizlii(Sakarya) [North West $0.6 \mathrm{Km}]$ \\
\hline 75 & 19670722203540 & 40.7900 & 30.4200 & 004.0 & 5.0 & Köprübaş1-Adapazarı (Sakarya) [South West $1.7 \mathrm{Km}$ ] \\
\hline 76 & 19670722194730 & 41.0700 & 30.5900 & 059.0 & 4.9 & Konacık-Karasu (Sakarya) [North West $0.7 \mathrm{Km}$ ] \\
\hline 77 & 19670722181400 & 40.7000 & 30.8000 & 010.0 & 4.5 & Bakacak-Hendek (Sakarya) [South West $0.5 \mathrm{Km}$ ] \\
\hline 78 & 19670722180955 & 40.7200 & 30.5100 & 035.0 & 5.4 & Ekinli-Erenler (Sakarya) [North East $3.5 \mathrm{Km}$ ] \\
\hline 79 & 19670722180854 & 40.7000 & 30.8000 & 010.0 & 4.8 & Bakacak-Hendek (Sakarya) [South West $0.5 \mathrm{Km}$ ] \\
\hline 80 & 19670722174806 & 40.6600 & 30.6200 & 026.0 & 5.2 & Alaağac-Akyazı (Sakarya) [North West $0.5 \mathrm{Km}]$ \\
\hline 81 & 19670722173007 & 40.7300 & 30.5300 & 010.0 & 5.1 & Bediltahirbey-Akyazı (Sakarya) [South West $2.7 \mathrm{Km}$ ] \\
\hline 82 & 19670722171854 & 40.7000 & 30.8000 & 010.0 & 4.5 & Bakacak-Hendek (Sakarya) [South West $0.5 \mathrm{Km}$ ] \\
\hline 83 & 19670722171410 & 40.7000 & 30.8000 & 006.0 & 5.5 & Bakacak-Hendek (Sakarya) [South West $0.5 \mathrm{Km}$ ] \\
\hline 84 & 19670722165658 & 40.6700 & 30.6900 & 033.0 & 6.2 & Güzlek-Akyazı (Sakarya) [North 1.5 Km] \\
\hline 85 & 19670407174007 & 40.0000 & 31.0000 & 010.0 & 4.5 & Belkese-Alpu (Eskișehir) [East $0.9 \mathrm{Km}$ ] \\
\hline 86 & 19661230015709 & 40.7400 & 30.7400 & 031.0 & 4.5 & Suleymaniye-Hendek (Sakarya) [South West $0.2 \mathrm{Km}$ ] \\
\hline 87 & 19641213140902 & 40.7000 & 31.0000 & 010.0 & 4.5 & Camlıbel-Gölyaka (Duzce) [South West $4.3 \mathrm{Km}$ ] \\
\hline 88 & 19581123130738 & 40.4900 & 30.6900 & 010.0 & 4.6 & Kaşıkçışeyhler-Göynük (Bolu) [North 2.5 Km] \\
\hline 89 & 19570602011200 & 40.7100 & 30.7800 & 010.0 & 4.9 & Kizanlik-Hendek (Sakarya) [South West $1.6 \mathrm{Km}$ ] \\
\hline 90 & 19570601210820 & 40.6800 & 30.8400 & 040.0 & 4.9 & Kurtuluş-Hendek (Sakarya) [South East 1.2 Km] \\
\hline 91 & 19570601052659 & 40.7500 & 30.8600 & 050.0 & 5.3 & Değirmentepe-Gölyaka (Duzce) [North West $1.8 \mathrm{Km}$ ] \\
\hline
\end{tabular}


Avrupa Bilim ve Teknoloji Dergisi

\begin{tabular}{|c|c|c|c|c|c|c|}
\hline 92 & 19570530142951 & 40.6500 & 31.2400 & 010.0 & 4.5 & Samandere (Düzce) [South West $5.5 \mathrm{~km}$ ] \\
\hline 93 & 19570530130756 & 40.6200 & 31.7800 & 010.0 & 4.5 & Caygökpınar (Bolu) [Southeast $11.0 \mathrm{Km}]$ \\
\hline 94 & 19570529101748 & 40.8300 & 30.7700 & 020.0 & 5.2 & Nuriye-Hendek (Sakarya) [North East $2.0 \mathrm{Km}$ ] \\
\hline 95 & 19570529084752 & 40.7200 & 31.0400 & 020.0 & 4.9 & Güzeldere-Gölyaka (Duzce) [South $0.6 \mathrm{Km}$ ] \\
\hline 96 & 19570528053348 & 40.5700 & 31.0200 & 040.0 & 4.9 & Taskesti-Mudurnu (Bolu) [South East $1.1 \mathrm{Km}$ ] \\
\hline 97 & 19570528000953 & 40.5800 & 30.5300 & 050.0 & 4.9 & Ahmediye-Karapürçek (Sakarya) [South West $3.8 \mathrm{Km}$ ] \\
\hline 98 & 19570527110134 & 40.7300 & 30.9500 & 050.0 & 5.8 & Saçmalıpınar-Gölyaka (Duzce) [South West $0.6 \mathrm{Km}$ ] \\
\hline 99 & 19570527082424 & 41.1300 & 30.6500 & 070.0 & 4.8 & Ihsaniye-Karasu (Sakarya) [North East $1.5 \mathrm{Km}$ ] \\
\hline 100 & 19570527070514 & 40.8400 & 31.1700 & 080.0 & 4.9 & Düzce (Düzce) [North East $0.6 \mathrm{Km}$ ] \\
\hline 101 & 19570527062037 & 41.1400 & 31.1900 & 080.0 & 4.5 & Beyhanl1-Akçakoca (Duzce) [North West $6.5 \mathrm{Km}$ ] \\
\hline 102 & 19570526093638 & 40.7600 & 30.8100 & 010.0 & 5.9 & Harmantepe-Hendek (Sakarya) [South $0.9 \mathrm{Km}$ ] \\
\hline 103 & 19570526091640 & 41.4200 & 31.0900 & 010.0 & 5.2 & Akçakoça- Açıkları-Düzce \\
\hline 104 & 19570526091359 & 41.3400 & 30.7000 & 100.0 & 5.3 & Kocaali Açıkları-Sakarya \\
\hline 105 & 19570526085451 & 40.6000 & 30.7400 & 040.0 & 5.5 & Durmușlar-Akyazı (Sakarya) [North West $1.0 \mathrm{Km}$ ] \\
\hline 106 & 19570526063335 & 40.6700 & 31.0000 & 010.0 & 6.7 & Güzeldere-Gölyaka (Duzce) [South West $7.1 \mathrm{Km}]$ \\
\hline 107 & 19560714190107 & 40.3200 & 30.9000 & 040.0 & 4.8 & Dedeler-Göynük (Bolu) [North East $0.6 \mathrm{Km}$ ] \\
\hline 108 & 19560106145259 & 41.0000 & 30.2000 & 010.0 & 5.2 & Mancarlar-Kandıra (Kocael1) [South East $0.9 \mathrm{~km}]$ \\
\hline 109 & 19520122231500 & 40.8000 & 30.4000 & 015.0 & 4.6 & Adapazarı (Sakarya) [North $2.4 \mathrm{Km}$ ] \\
\hline 110 & 19491128184718 & 40.9800 & 30.7400 & 010.0 & 4.9 & Kurudere-Karasu (Sakarya) [South West $0.3 \mathrm{Km}$ ] \\
\hline 111 & 19481213020000 & 41.0000 & 30.0000 & 015.0 & 4.5 & Hacışeyh-Kandıra (Kocael1) [North West $0.9 \mathrm{Km}$ ] \\
\hline 112 & 19450209022800 & 40.5000 & 31.2000 & 030.0 & 5.2 & Esenkaya-Mudurnu (Bolu) [South East $2.4 \mathrm{Km}$ ] \\
\hline 113 & 19440405044043 & 40.8400 & 31.1200 & 010.0 & 5.6 & Mamure (Düzce) [South East $0.8 \mathrm{Km}$ ] \\
\hline 114 & 19440202033317 & 40.7400 & 31.4400 & 040.0 & 5.3 & Elmalık (Bolu) [North West $1.4 \mathrm{Km}]$ \\
\hline 115 & 19440201060852 & 40.7000 & 31.2700 & 010.0 & 5.3 & Samandere (Düzce) [North East $0.6 \mathrm{Km}$ ] \\
\hline 116 & 19430906163247 & 40.2100 & 31.3500 & 010.0 & 5.2 & Akdere-Nallhan (Ankara) [North East $1.8 \mathrm{Km}$ ] \\
\hline 117 & 19430620164757 & 40.8400 & 30.7300 & 010.0 & 5.6 & Kahraman-Hendek (Sakarya) [North $3.0 \mathrm{Km}$ ] \\
\hline 118 & 19430620153254 & 40.8500 & 30.5100 & 010.0 & 6.4 & Turkbeylikkışla-Soğütlü (Sakarya) [South East $0.9 \mathrm{Km}$ ] \\
\hline 119 & 19400613110200 & 41.3400 & 30.1700 & 030.0 & 4.8 & Ağva Açıkları-İstanbul (Karadenız) \\
\hline 120 & 19330515032305 & 41.2600 & 31.0900 & 060.0 & 4.9 & Akçakoca Açıkları Düzce (Karadenız) \\
\hline 121 & 19330205053000 & 41.5000 & 31.5000 & 010.0 & 6 & Kozlu Açıkları Zonguldak \\
\hline 122 & 19321015221954 & 40.9000 & 30.6000 & 015.0 & 4.7 & Aktefek-Hendek (Sakarya) [South East $1.3 \mathrm{Km}$ ] \\
\hline 123 & 19290427221806 & 40.5100 & 31.4300 & 070.0 & 4.9 & Sarpinc1k-Mudurnu (Bolu) [South West $1.9 \mathrm{Km}$ ] \\
\hline 124 & 19290405231815 & 41.5000 & 31.5000 & 033.0 & 4.9 & Kozlu Açıkları-Zonguldak (Karadenız) \\
\hline 125 & 19290405082655 & 41.6100 & 31.2300 & 010.0 & 4.8 & Ereğli Açıkları-Zonguldak \\
\hline 126 & 19280124073611 & 40.9900 & 30.8600 & 010.0 & 5.5 & Kovukpelit-Kocaali (Sakarya) [South East $0.7 \mathrm{Km}$ ] \\
\hline 127 & 19261216175405 & 40.1300 & 30.7200 & 010.0 & 5.8 & Beyyayla-Sarıcakaya (Eskısehır) [South East $1.5 \mathrm{Km}$ ] \\
\hline 128 & 19250624000034 & 40.8800 & 30.3900 & 010.0 & 4.8 & Kayrancık-Adapazarı (Sakarya) [South East $4.4 \mathrm{Km}$ ] \\
\hline 129 & 19230529113402 & 41.0000 & 30.0000 & 025.0 & 5.6 & Hacışeyh-Kandıra (Kocael1) [North West $0.9 \mathrm{Km}$ ] \\
\hline 130 & 19070821000000 & 40.7000 & 30.1000 & 015.0 & 5.6 & Sirinsulhiye-Kartepe (Kocael1) [East $0.3 \mathrm{Km}$ ] \\
\hline 131 & 19051022034200 & 41.0000 & 31.0000 & 027.0 & 5.4 & Esmahanım-Akçakoca (Duzce) [North East $1.4 \mathrm{Km}$ ] \\
\hline 132 & 19050501190001 & 39.9000 & 31.1000 & 005.0 & 4.9 & Ağachisar-Alpu (Eskısehır) [South West $4.6 \mathrm{Km}$ ] \\
\hline
\end{tabular}




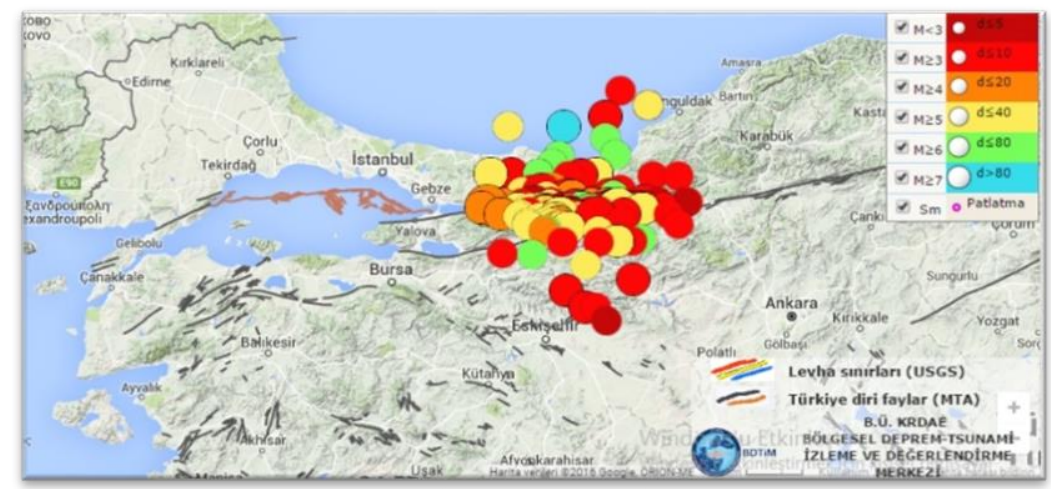

Şekil 2. Düzce ve çevresi $100 \mathrm{~km}$ çapında tarihsel depremlerin harita dağılımı [6]

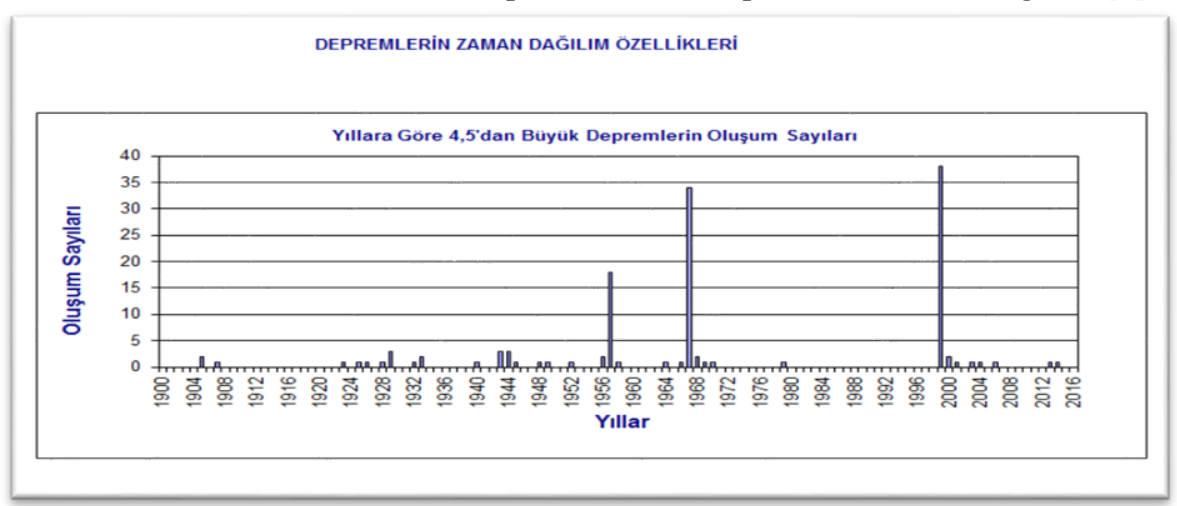

Şekil 3. Konuralp yerleşkesi 1900-2016 yılları arasında oluşmuş 4.5 ve daha büyük depremlerin dağılım grafiği [6]

Düzce ve $100 \mathrm{~km}$ çevresindeki 4,5'den büyük deprem kayıtlarından hareketle, inceleme alanı için Poisson Olasılık Dağılımı ile Probabilistik Deprem Tehlike Analizi yapılmıştır. Analizde, Mikrosoft ${ }^{\circledR}$ exel yazılım programı kullanılmıştır [7]. Depremsellik açısından, Düzce ve çevresini etkileyen Düzce fayının başlıca ana kaynağı KAFZ'dur. Dolayısıyla, Düzce ilinin deprem tehlikesini belirlemede, çalışma alanı için deprem oluşturma potansiyeli olarak Düzce fayının deprem üretme potansiyelinin varlığı dikkate alınmaktadır. Düzce Fayı için 12 Kasım 1999 depreminde yaklaşık 45 km'lik fay segmenti kırılmış ve $\mathrm{Mw}=$ 7,2 büyüklüğünde bir deprem üretmiştir. 116 yıllık kayıtlara göre hesaplanan 100 y1llık olasılık değerleri, Çizelge 2 ve Çizelge 3'de verilmiştir. Deprem risk analizi program çıktıları ise Şekil 4'de sunulmuştur [7]. Çizelge 2. Probabilistik deprem tehlike analizi

\begin{tabular}{|c|c|c|c|c|c|}
\hline \multicolumn{6}{|c|}{ PROBABİLISTIK DEPREM TEHLIKE ANALİZI } \\
\hline \multicolumn{6}{|c|}{ YIL 116} \\
\hline \multicolumn{6}{|c|}{ Poison Olasılık Dağılımı ile Deprem Risk Analizi } \\
\hline Regresyon için Veri Sayısı & 5 & & & & \\
\hline Magnitüd Aralıkları & $4.5 £ \mathrm{M}<5.0$ & $5.0 £ \mathrm{M}<5.5$ & $5.5 £ \mathrm{M}<6.0$ & $6.5 £ \mathrm{M}<7.0$ & $7.0 £ \mathrm{M}<7.5$ \\
\hline Ni (Oluşum Sayıları) & 28 & 13 & 3 & 0 & 2 \\
\hline Ortalama Magnitüd M yada (Xi) & 4,7 & 5,2 & 5,7 & 6,7 & 7,2 \\
\hline SNi (Kümülatif Oluş Sayıları) & 46 & 18 & 5 & 0 & 2 \\
\hline $\mathrm{SNi} / \mathrm{t}$ & 0,396551724 & 0,155172414 & 0,0431 & 0 & 0,017241 \\
\hline Log SNi/t yada (Yi) & $-0,401700158$ & $-0,809185484$ & $-1,3655$ & 0 & $-1,76343$ \\
\hline SXi & 29,5000000 & & $\mathrm{a}$ & 0,464189379 & \\
\hline SYi & $-4,3398016$ & & $\mathrm{~b}$ & $-0,225788085$ & \\
\hline $\mathrm{SXi}^{\wedge} 2$ & 178,3500000 & & & & \\
\hline SXiYi & $-26,5757183$ & & $\log (N)=a-b^{*} M$ & & \\
\hline $\mathrm{S}(\mathrm{Xi})^{\wedge} 2$ & 870,2500000 & & & & \\
\hline
\end{tabular}




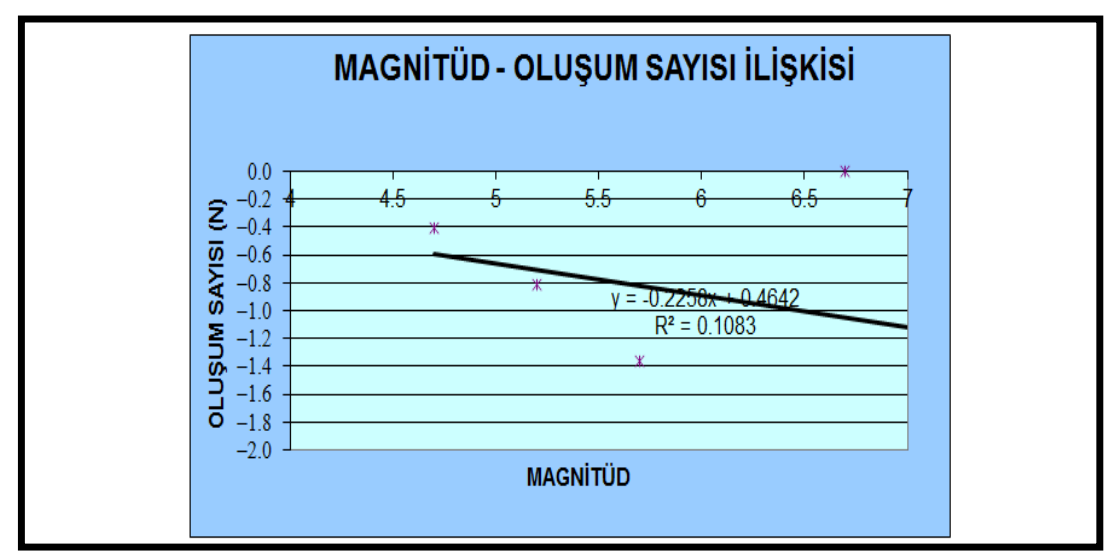

Şekil 4. poisson olasıllk dağılımı ile hesaplanan farklı büyüklükteki depremlerin farklı zaman süreleri için oluşum olasılıkları ve aşılma oranları

Çizelge 3. Poisson olasılık modeli için magnitüd-oluşum saylsı ilişkisi

\begin{tabular}{|c|c|c|c|c|c|c|}
\hline \multicolumn{7}{|c|}{ Poison Olasılık Dağılımı } \\
\hline & & & & $\mathrm{Rm}=1-\mathrm{e}-(\mathrm{N}(\mathrm{M}) * \mathrm{D})$ & & Ortalama \\
\hline & & $\begin{array}{l}\text { D (Yıl) için } \\
\text { Olasılık (\%) }\end{array}$ & $\begin{array}{l}\text { D (Yıl) için Olasilık } \\
(\%)\end{array}$ & $\mathrm{D}(\mathrm{Y} 1 \mathrm{l})$ için Olasılık (\%) & $\mathrm{D}(\mathrm{Y} 1 \mathrm{l})$ için Olasılık (\%) & $\begin{array}{l}\text { Tekrarlama } \\
\text { Periyodu }\end{array}$ \\
\hline $\mathrm{N}(\mathrm{M})$ & Magnitüd & 10 & 50 & 75 & 100 & (Y1l) \\
\hline 0,280636 & 4,5 & 94,0 & 100,0 & 100,0 & 100,0 & 4 \\
\hline 0,216396 & 5 & 88,5 & 100,0 & 100,0 & 100,0 & 5 \\
\hline 0,166861 & 5,5 & 81,1 & 100,0 & 100,0 & 100,0 & 6 \\
\hline 0,128665 & 6 & 72,4 & 99,8 & 100,0 & 100,0 & 8 \\
\hline 0,076502 & 7 & 53,5 & 97,8 & 99,7 & 100,0 & 13 \\
\hline 0,068947 & 7,2 & 49,8 & 96,8 & 99,4 & 99,9 & 15 \\
\hline
\end{tabular}

Çizelge 4. Poisson Olasıllı Dă̆̆llımı ile Hesaplanan Farklı Büyüklükteki Depremlerin 50 Yıl İçin Aşılma Oranlart

\begin{tabular}{|c|c|c|}
\hline $\mathrm{D}(\mathrm{y} 1 \mathrm{l})$ & \% Aşılma Olasılı̆̆ & M (magnitüd) \\
\hline 50 & 96,8 & 7,2 \\
\hline
\end{tabular}

Çalışma alanı için deterministik analiz başlığı altında belirlenmiş olan, tek kaynak modellemesinde Düzce Fayı için 7,2 büyüklüğündeki depremin 50 yıllık süreçte aşılma olasılığı $\% 96,8$ olarak hesaplanmıştır (Çizelge 4). Çalışma alanı tasarım depremi için, analiz programı, $2 \mathrm{~km}$ episentral uzaklık ve $10 \mathrm{~km}$ odak derinliği kabulü ile belirtilen aşılma oranında, beklenen ivme değeri ve bu değerin European Seismological Commision'a göre tehlike düzeyi yüksek tehlike düzeyindedir (Çizelge 5). Büyüklüğü 7,2 olan tasarım depreminin 50 yıl ve $\% 96,8$ aşılma oranı için $2 \mathrm{~km}$ episentral uzaklık ve $10 \mathrm{~km}$ odak derinliğinde beklenen ivme değerine karşlık tehlike düzeyi yüksek tehlikedir.

Çizelge 5. European Seismological Commision'a (ESC) Göre, ivme değeri - tehlike Düzeyleri ilişkisi

\begin{tabular}{|c|c|}
\hline \multicolumn{2}{|c|}{ Europan Seismological Commision'a (ESC) Göre } \\
\hline Tehlike Düzeyi & İvme Değerleri \\
\hline Düşük Tehlike & $<0,08 \mathrm{~g}$ \\
\hline Orta Tehlike & $0,08 \mathrm{~g}-0,24 \mathrm{~g}$ \\
\hline Yüksek Tehlike & $>0,24 \mathrm{~g}$ \\
\hline
\end{tabular}




\subsection{Konuralp Yerleşim Yerini Etkileyecek Faylar ve Büyüklüklerinin Deterministik Yöntemle Hesaplanması}

Düzce ve Çevresi KAFZ etkisi altındadır ve sismik olarak aktif bir kuşaktır. Hem tarihi kayıtlara hemde aletsel kayıtlara bakıldığında bu bölgenin aktif olduğu ve çok sayıda yıkıcı depremlerin oluştuğu görülmektedir. Bölgede bu bağlamda geçmiş döneme ait medeniyetlerin kalıntıları bulunmaktadır. $\mathrm{Bu}$ harabeler ve kalıntılar bu yörede dönemsel olarak ciddi yıkıcı depremlerin olduğunu ortay koymaktadır. Çalışma alanında etkinliği bilinen Düzce Fayı 17 Ağustos ve 12 Kasım 1999 y1lında deprem büyüklüğü $\mathrm{Mw}=7,6$ ve $\mathrm{Mw}=7,2$ büyüklüğünde 2 adet deprem üretmiştir. Düzce ve çevresini etkileyecek olan fay yine aktifliği ve büyüklüğü ile bilinen Düzce fayı olacaktır. Tarihi ve arkeolojik kalıntılara bakıldığında muhtemelen bu fayın ürettiği depremin tarihi Prusias ad Hypium antik kentini yıktığı tahmin edilmektedir (Şekil 6).

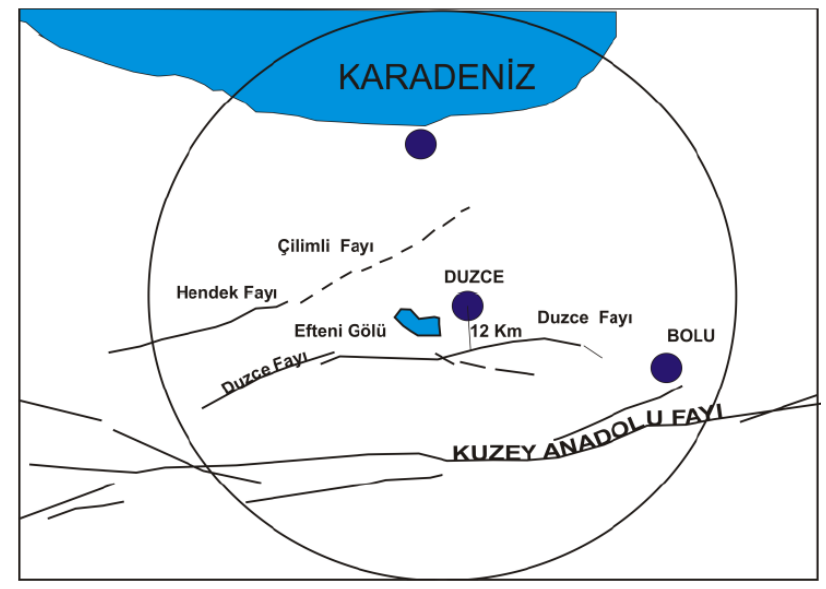

Şekil 6. Düzce ve Çevresini etkileyen faylar

Dünyada olmuş olan depremler ve faylar incelendiğinde genel olarak fay segmenti $1 / 2$ oranında fay uzunluğu olarak bakıldığında ise $1 / 3$ oranında kırıldığı kayıtlara ve raporlara geçmiştir [8]. Çalışma alanını etkilemesi düşünülen Düzce fayının üreteceği depremin moment büyüklüğü Wells and Coppersimith [9] eşitliği ile tahmin edilebilmektedir.

\section{Mw=4,86+1,32 Log L Eş. (1)}

Burada Mw: Fayın ürettiği enerjiye bağlı deprem büyüklüğü, L ise fay uzunluğunu (km) göstermektedir. Çalışma alanında bu Düzce Fayı segmentinin kırılması halinde yaklaşık $\mathrm{Mw}=7,2$ büyüklüğünde bir deprem üretme potansiyelinin olduğu görülmektedir. Depremlerde yapıya gelecek deprem yükünü gösteren esas büyüklük depremin oluşturacağı ivme ile ölçülür. $\mathrm{Bu}$ nedenle çalışma alanında etkin olan fayın üreteceği ivme büyüklüğü ise Ulusay vd. [10] eşitliği ile tahmin edilebilmektedir.

$\mathrm{PGA}=2,18 \mathrm{e} 0,0218(33,3 \mathrm{Mw}-\mathrm{Re}+7.8427 \mathrm{SA}+18.9282 \mathrm{SB})$

Burada; yumuşak zeminler için $\mathrm{S}_{\mathrm{A}}=0, \mathrm{~S}_{\mathrm{B}}=1$ alınır. Re: yerleşim yerine olan kuş uçuşu en yakın dikey mesafedir. Mw: Deprem büyüklüğüdür.

$\mathrm{Bu}$ durumda burada oluşacak deprem yatay ivmesinin büyüklüğü $\mathrm{a}_{\max }=0,51 \mathrm{~g}$, hatta ilk depremin olduğu anda $0,81 \mathrm{~g}$ olarak kayıtlara geçmiştir. Bu büyüklük ciddi bir deprem büyüklüğüdür. Yapı hasarlarına oluşması için yeterlidir. $\mathrm{Bu}$ bağlamda Prusias ad Hypium Antik Kentinde ciddi can ve mal kayıplarına neden olduğu tarihi kayıtlardan anlaşılmaktadır. Düzce Meteoroloji Müdürlüğü istasyonunda bulunan ivme-ölçer, Doğu- Batı yönünde $513 \mathrm{~cm} / \mathrm{sn}^{2}$ lik bir ivme değeri ölçmüştür. Depremin dış merkezine (episantr) uzaklığı yaklaşık $60 \mathrm{~km}$ olan Sakarya Bayındırlık ve İskân Müdürlüğü'ndeki istasyonda ise, maksimum yatay pik ivme $25 \mathrm{~cm} / \mathrm{sn}^{2}$ olarak gerçekleşmiştir. Alüvyon bir zemin üzerinde olan Düzce istasyonuna karşıt, Sakarya'da nispeten kayalık bir zeminde bu değerler alınmıştır. Düzce ve Sakarya da alınan ivme katsayılarının Fourier spektrumu deprem dalgasının frekansı olan 1-10 Hz. arasında Butterworth-Band Pass filtreden geçirip gerekli düzeltmeler yapılarak hesaplanmıştır. Sakarya kaydının frekansı 5,6 Hz. yani periyodu 0,18 sn'dir. Düzce kaydının frekansı $2,3 \mathrm{~Hz}$ ve hakim periyodu 0,4 sn. dir. Düzce kaydının maksimum ivme genliğinin Doğu- bat1 yönlü 513,7 gal, kuzey- güney yönlü 407,6gal ve düşey yönde ise 339,61 gal olduğu dikkate alınırsa Prusias ad Hypium Antik Kentinin yıkılmasının nedeni anlaşılabilecektir.

\section{Depremlerde Hasar Görmüş̧ Antik Yapıların İncelenmesi}

\subsection{Prusias Ad Hypium}

Prusias ad Hypium Antik Kenti, Düzce il merkezi Konuralp kasabasında yer almaktadır. Tarihi M.Ö. 3. yüzyıla kadar uzanan kent antik Bithynia Bölgesi'nde Hypios (Melen Çayı) kenarında kurulmuş olduğu tarihi kalıntılardan anlaşılmaktadır [11]. Geçmişten günümüze bu bölge bir çok medeniyete ev sahipliği yapmıştır. Ancak bilinen Düzce antik tarihinin Romalılar hakimiyetinde yaşandığı tarihi kalıntılara 
Avrupa Bilim ve Teknoloji Dergisi

bakınca daha net anlaşılabilmektedir. Bu bağlamda Düzce ilinin kuzeyinde yer alan ve yerel kültürde kasaba olarak tanımlanan bu günkü adı ile Konuralp olarak bilinen yerleşkede geçmiş depremlerden hasar görmüş tarihi yapılar ve harabeler mevcuttur. Bu harabeler bu bölgede geçmiş de yaşanmış aletsel ve tarihsel dönemde büyük depremlerin izlerini taşımaktadır. Bu bölgede meydana gelen depremler nedeniyle Prusias'a ait yapılar günümüzde Konuralp olarak bilinen kasabanın altında kaldığ kazılardan ve kalıntılardan ortaya çıkarılmıştır [12].

\subsection{Prusias ad Hypium (Kieros, Üskübü, Kasaba, Konuralp) kenti kalıntıları}

\subsubsection{Surlar ve Sanatsal Yaptlar}

Kent ovadan gelebilecek saldırılara karşı arkasını dağa doğru yaslanmış alarak tepeye kurulmuştur. Çevresi surlarla kuşatılmıştır. Kentin savunma hattını oluşturan kuleler ve duvarlar, araziyle uyumlu bir biçimde inşa edilmiştir [14]. Kale duvarları, birbiri üzerine konan yazıtlı sunaklar, kaideler, tiyatroya ait oturma yerleri (40 basamak) büyük bloklarla yapılmıştır. Akçakoca yolunu kente bağlayan yol üzerinde bulunan üzerinde at resmi olan kapı "Atlı kapı" olarak
Düzce kent merkezinin yaklaşık $10 \mathrm{~km}$ kuzeyinde bu günkü adı ile anılan Konuralp Yerleşkesi sınırları içinde kurulduğu tarihi kalıntılardan anlaşılmaktadır. Antik kentin tarihi M.Ö.3. yüzyıla kadar dayanmakta; kurulmasında ve gelişmesinde tarıma elverişli Hypios Irmağı'nın etkili olduğu ve ismini buradan aldığı düşünülmektedir $[13,14]$. Bu bölgede tarihi dönemlerde meydana gelen depremde zarar görmüş harabeler ve kalıntılar bugünkü adı ile Konuralp yerleşkesi olarak adlandırılan ilçe merkezi altında Prusias'a ait olduğu bilinen tarihi kalıntılar ve harabeler bulunmaktadır. Prusias Anadolu'nun kuzeybatısında, doğu ile batıyı birbirine bağlayan yollar üzerinde kurulmuştur. bilinmekte ve kentin bir diğer savunma duvarıdır (Şekil 7-10). Kapının üzerinde at resmedilmiş, üzerinde Grekçe bir yazıt vardır ve üzerinde Prusiaslı'nın annesine yaptırdığı mezar steli olan büyük bir lento mevcuttur. Kapıdan itibaren güneydoğu yönünde uzanan sur duvarı kare planlı bir kuleye bağlanmaktadır [14]. Konuralp Beldesi'nde yer alan Genç Hellenistik-Erken Roma dönemlerine ait sur duvarları, köprü, su kemerleri, atlı kap1 ve tiyatro Prusias ad Hypium antik kentinden günümüze kadar ulaşan başlıca mimari eserlerdir.

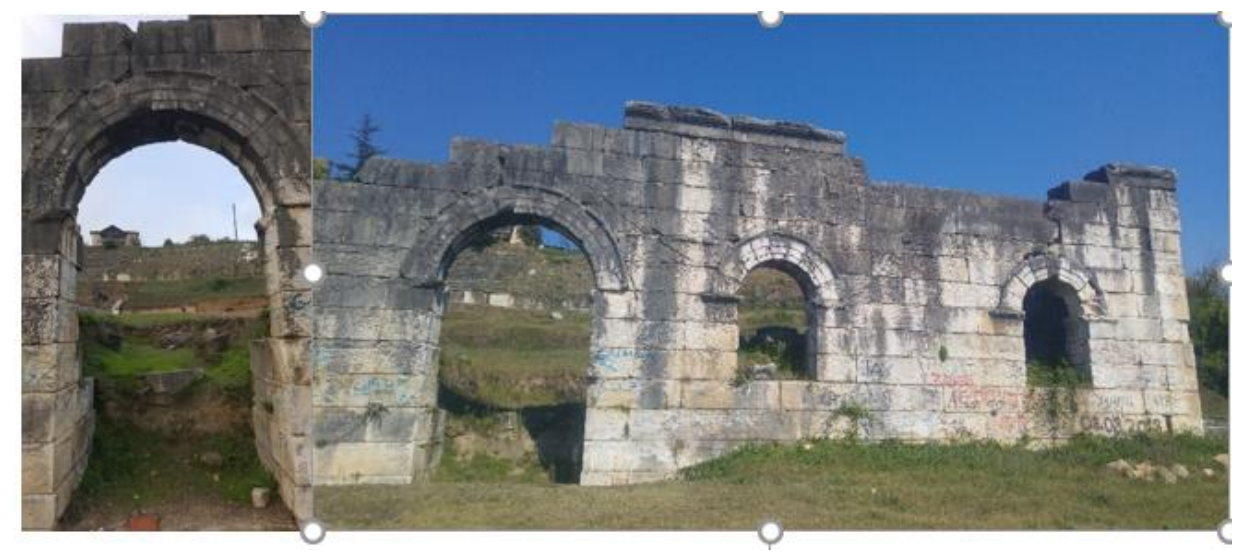

Şekil 7. Roma dönemlerine ait sur duvarlart

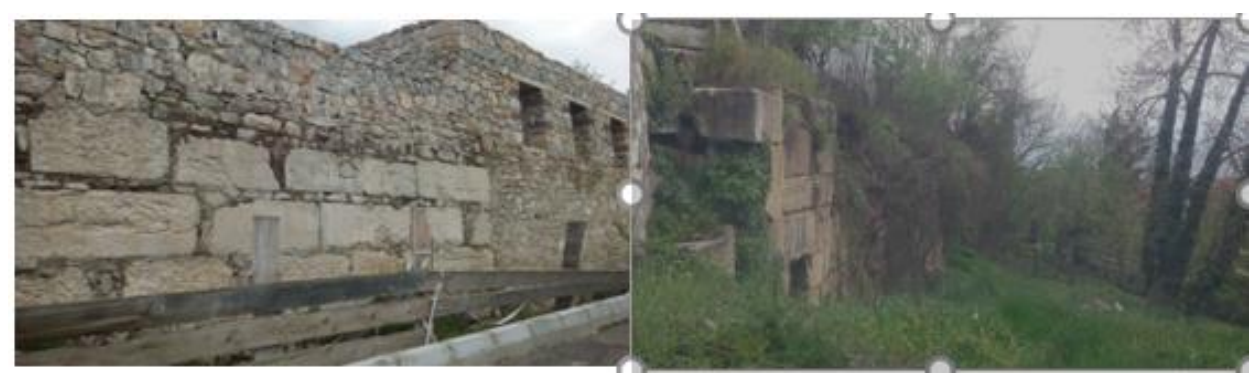

Şekil 8. Roma dönemlerine ait sur duvarlarl

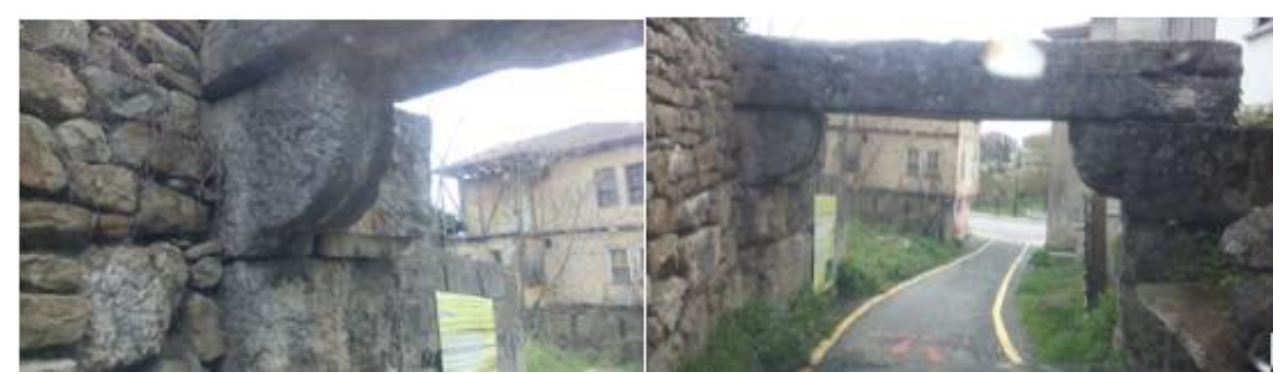

Şekil 9. Tarihi Atlı kapı şehir giriş kapısı 


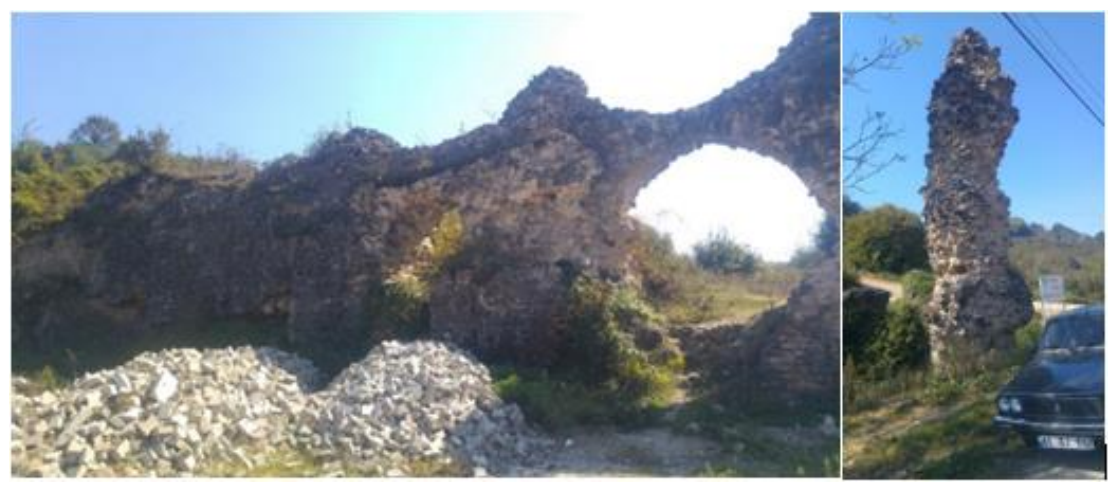

Şekil 10. Roma (Prusias ve Hypium) dönemine ait su kemerleri

Roma İmparatorluğu'nun doğuya yaptığı seferlerde Prusias'a uğradıkları bilinmektedir. Roma'nın doğusuna doğru buradan yol uzandığı ve uzanan anayollarından biri olan Kuzey yolunun Prusais'tan geçtiği Hypios Çayı üzerine inşa edilen 3 gözlü taş köprüye ait harabelerden anlaşılmaktadır (Şekil 11-12). Tarihi köprüden, surlardan, su kemerlerinden ve diğer tarihi kent eserlerinden bugün sadece enkazı kalmıştır. Düzce Valiliği tarafindan korunma altına alınarak Konuralp Müzesine kazandırılmıştır. Ayrıca kazılarda tarihi köprünün etrafında bir insan iskeletine de rastlanılmıştır. Bu olay tarihi kent eserlerinin bir depremde yıkıldığını ve enkaz altında can ve mal kayıplarının yaşanmış olduğunu göstermektedir.
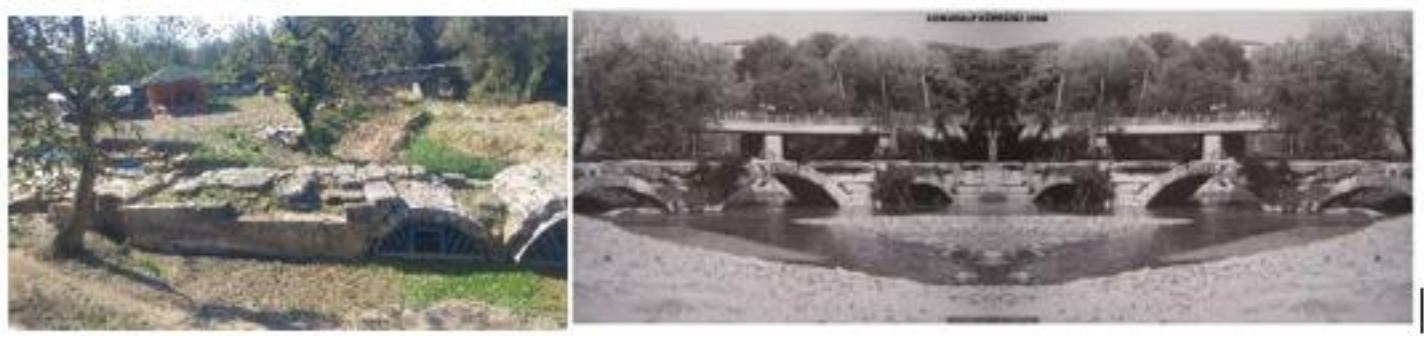

Şekil 11. Tarihi Roma dönemine ait üç gözlü köprü

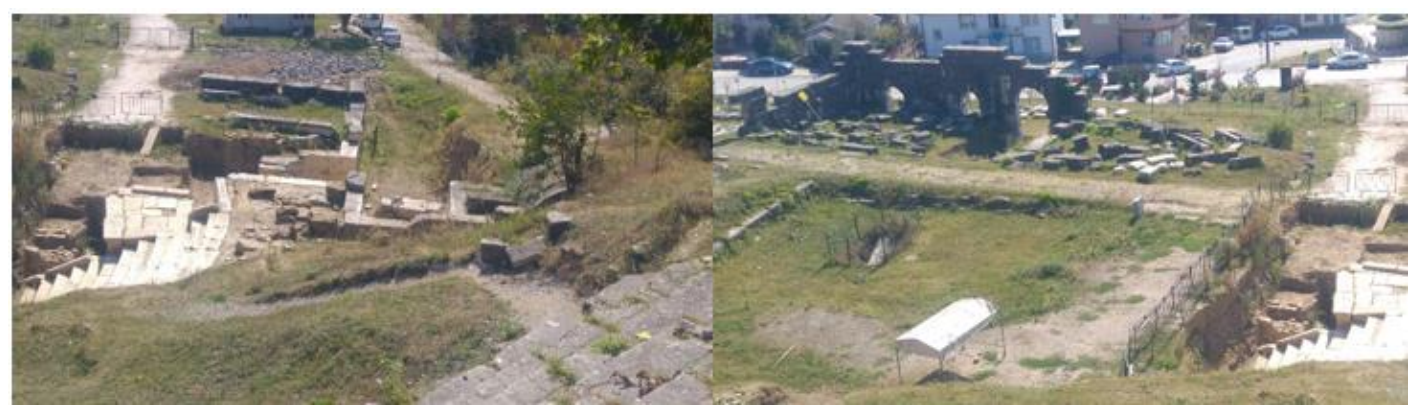

Şekil 12. Prusias ve Hypium Tarihi Konuralp Harabeleri

\subsubsection{Tiyatro}

Kentte bulunan Roma dönemi antik tiyatrosunun bir kısmı hala ayakta olmakla birlikte zamana yenik düşmüştür. Ancak hala kalıntıları mevcuttur. Bu bölgede günümüzü kadar gelebilen tek tiyatro Prusias ad Hypium kent tiyatrosunun olduğu bilinmektedir. Antik Tiyatro (Prusias Tiyatrosu) M.Ö. 10-M.S. 20 yılları arasında inşa edilmiştir. Yapıldığı dönemin en görkemli eserlerinden biri olarak bilinmektedir. 77x100 m ölçülerinde bir oturma alanına sahiptir. Doğu Bithynia bölgesinde ayakta kalmış tek antik tiyatrodur (Şekil 13-14). Günümüzde antik kent tiyatrosunun sadece kalıntıları mevcuttur. Antik dönemde olmuş olan depremlerin etkisinde yıkıldı̆̆ 1 enkaz altında kaldığı düşünülmektedir [15]. 


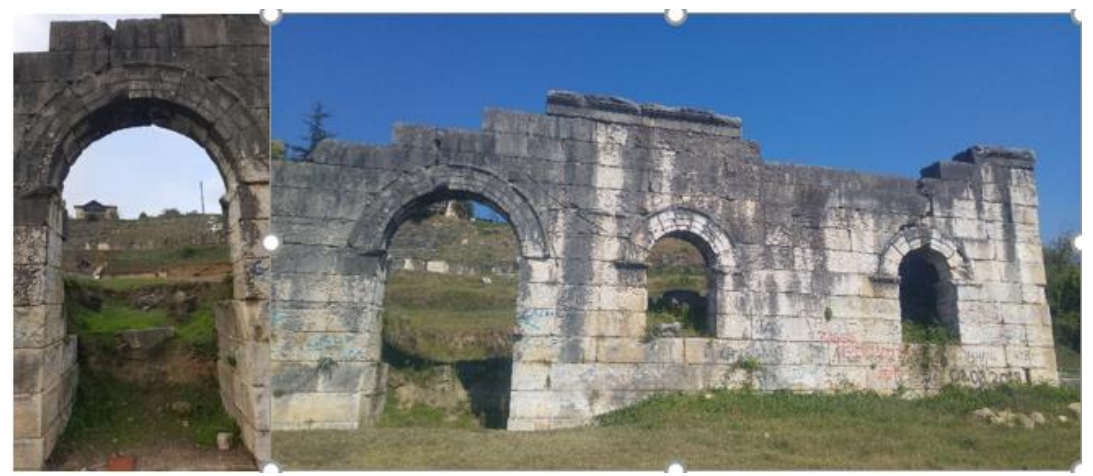

Şekil 13. Antik Tiyatro giriş kapısı
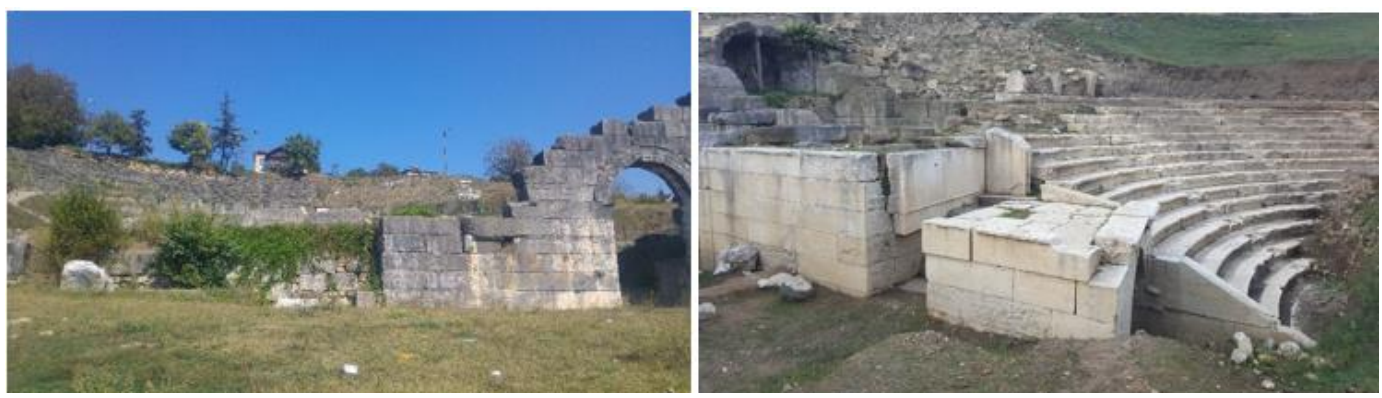

Şekil 14. Prusias ve Hypium Antik tiyatro harabeleri

\section{Sonuçlar}

Düzce ilinin de yer aldığı Batı Kara Deniz ve Doğu Marmara Bölgesi hem aletsel hem de tarihsel dönemlerde yoğun zemin hareketliliğinin yaşandığı anlaşılmaktadır. Bu bölgede hasar yapıcı depremler olarak 6 ve üzerinde depremlerin meydana geldiği aletsel ve tarihsel kayırlardan ve günümüze kadar gelen tarihi eserlerden ve kalıntılarından anlaşılmaktadır. Günümüzde deprem etkisinin yoğun olarak görüldüğü Kuzey Anadolu Fay Zonu üzerinde tarihsel dönemde oldukça fazla deprem yoğunluğu yaşandığı ve yıkıcı etkisinin oluştuğu çalışma alanındaki (Prusias ad Hypium) tarihi enkazlardan ve harabelerden anlaşılmaktadır. Zira bu bölge KAFZ zonu üzerinde yer aldığından Anadolu Plakasının batıya doğru hareketine bağlı olarak aktif bir bölgedir. Son 17 Ağustos 1999 Adapazarı ve 12 Kasım 1999 Düzce depreminde ciddi mal ve can kayıplarının meydana geldiğini ortaya koymuştur. Düzce ve civarında bu günkü adı ile Konuralp kasabası olarak bilinden (Prusias ad Hypium) tarihi kentinde ortaya çıkan Roma dönemi kalıntılarına bakıldığında bu bölgenin tektonik hareketliliği açısından ciddi risk taşıdığı ortaya konulmuştur. Tarihsel ve aletsel dönemlerde Konuralp (Prusias ad Hypium) kent merkezini etkileyen depremlerde depremin Roma dönemi sanatsal yapılarına etkisinin araştırıldığı bu araştırma makalesinde kent merkezinde M.Ö. 3. Yüzyılda inşa edilen antik yapılar araştırılmıştır. Bu araştırma sonucunda;

Roma dönemi antik yapılarının günümüze kadar ulaşamadıkları bu bölgede meydana gelen depremlerde yıkıldığ ancak kalıntılarının günümüze miras olarak kaldığı görülmüştür. Ayrıca yapısal inşa tarzlarının anlaşılabildiği kemer ve tonoz şeklinde olan yapıların tam olmasa da kısmi olarak ayakta kaldıkları, kesme taş veya moloz kagir taşlardan inşa edilmiş yapıların nerdeyse yıkıldığı veya yıkılma noktasına geldiği anlaşılmaktadır. $\mathrm{Bu}$ bilgiler 1şığında tarihi kent yapılarının neredeyse bütününün yıkılmış olduğu tahmin edilmektedir. $\mathrm{Bu}$ harabeler Düzce Valiliği Konuralp Müze Müdürlüğü tarafından koruma altına alınarak tarihe kazandırılmıştır. Yıkıcı etki yaratabilecek aktif fay hatları bulunan Düzce İli deprem tehlikesi açsından önemli bir konumdadır. Son olarak 17 Ağustos 1999 ve 12 Kasım 1999 depremleri bunu göstermiştir. Bu bölge göç alan bir bölge konumundadır, hızlı yapılaşma trendi içine girmiştir. Geçmişte meydana gelmiş tarihi ve aletsel depremlerden ders çıkararak yeni yapılacak yapıların doğru ve sağlam zeminler üzerine ve deprem yönetmeliğine uygun, inşa edilmesi ile olabilecek yıkıcı deprem hasarlarının cana ve mala zarar vermesi önlenebilecektir.

\section{Teşekkür}

Düzce Konuralp Müzesi Müdürlüğü’ne Konuralp Yerleşkesindeki Yaptığı Kazı Çalışmalardan Dolayı Teşekkür Ederim.

\section{Kaynaklar}

[1]. MTA. Genel müdürlüğü ve Ankara Üniversitesi (A.U).1999, 17 Ağıstos 1999 Depremi sonrası Düzce (Bolu) İlçesi Alternatif Yerleşim alanlarının Jeolojik İncelenmesi. TUBITAK Yer Deniz Atmosfer Bilimleri ve Çevre Araştırma Grubu Raporu 59s.

[2]. B. Özzmen. (1912). Türkiye Deprem Bölgeleri Haritalarının Tarihsel Gelişimi, Türkiye Jeoloji Bülteni, c. 55,s.1,ss.4355, 2012.

[3]. Şengör A.M.C. (1981). Y1lmaz Y., "Tethyan evolution of Turkey: a plate tectonic approach", Tectonophysics, 75: 181-241, (1981).

[4]. M.T.A, Genel Müdürlüğü ve Ankara Üniversitesi (A.U). (1999). "17 ağustos 1999 depremi sonrası düzce (bolu) ilçesi alternatif yerleşim alanlarının jeolojik incelenmesi”, TÜBITAK Yer Deniz Atmosfer Bilimleri ve Çevre Araştırma Grubu Raporu, Ankara. 
[5] B. Özmen, G. Bağc1. (2000)."12 kasım 1999 Düzce depremi raporu", T.C. Bayındırlık ve iskan bakanlığı afet işleri genel müdürlüğü deprem araştırma dairesi, Türkiye, 2000.

[6].Boğaziçi Üniversitesi Kandilli Rasathanesi ve Deprem Araştırma Enstitüsü Bölgesel Deprem -Tsunami İzleme ve Değerlendirme Merkezi. 2016.

http://www.koeri.boun.edu.tr/sismo/2/tr/,(2016).

[7] Zemin Jeofizik Analiz, Bilgisayar Programı, Microsoft ${ }^{\circledR}$ Excel Programı: İ.Ü. Müh. Fakültesi Jeofizik Mühendisliği Bölümü, 2005.

[8]. Mark R. K. (1977).“Application of linear statistical model of earthquake magnitude versus fault length in estimating maximum expectable earthquakes", Geology, 5: 464- 466, (1977).

[9]. Wells, D.L. and K.J. (1984). “Coppersmith, New empirical relationships amoung magnitude, rupture length, rupture width, rupture area, and surface displacement", Bull, Seismol. Soc, 84: 974-1002, (1984).

[10].Ulusay R., Tuncay E., Sonmez H. and Gokceoglu C. (2004). "An attenuation relationship based on Turkish strong motion data and iso-acceleration map of Turkey", Engineering Geology, 74: 265-291, (2004).

[11].Dikmen, B., Ç. ve Toruk, F. (2017). Prusias ad Hypium Antik Kenti Üzerinde Bir Yerleşim: Konuralp, Researcher Social Science Studies, 5(4), 176-210.

[12]. Akıncı Kesim, G., Köylü, P. ve Girti, P. (2009). Roma Dönemi Kent Yerleşimleri ve Prusias ad Hypium (Kieros, Üskübü, Konuralp), Düzce Üniversitesi Ormancılık Dergisi, 1: 5-24.

[13].Kurt, M. (1979). Prusias ad Hypium'un (Konuralp) Arkeolojik Yapısı. Atatürk Üniversitesi Edebiyet Fakültesi, Arkeoloji Bölümü Basılmamı_Bitirme Tezi. Erzurum.

[14]. Zeyrek, T., Çelik, G.B. (2005). Prusias ad Hypium (Kieros) Anadolu'nun Kuzeybatısında Antik Bir Kent (Konuralp/Üskübü). Ege Yayınları. İstanbul.

[15].Akkoyunlu, M.F. (2021). Tarihsel Depremler ve Kullanılan Yöntemler, Avrupa Bilim ve Teknoloji Dergisi Sayı 21, S. 587-590, Ocak 2021. 